\title{
Leafhopper Funa Associated with Paddy Crop-Ecosystems in Rayalaseema Region of Andhra Pradesh, India
}

\author{
S. Nagesh*, M.S.V. Chalam, S.R. Koteswara Rao and B. Ravindra Reddy
}

Acharya N G Ranga Agricultural University, Dept. of Entomology, S V Agricultural College, Tirupati, 517502, Chittoor District (A.P.), India

*Corresponding author

\section{A B S T R A C T}

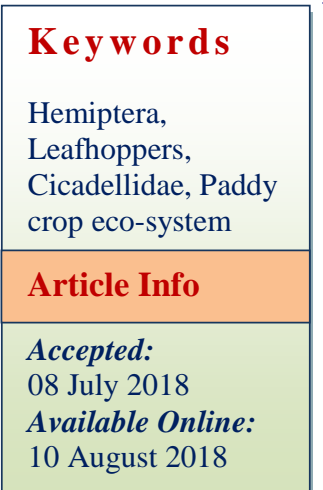

\section{Introduction}

Leafhoppers, an economically important group of Auchenorrhynchan Hemiptera belong to the family Cicadellidae comprising about 2,445 described genera and 22,637 species in world wide and 340 genera and 1,350 species in India (Viraktamath, 2006). Leafhoppers are small wedge shaped insects of various forms, colours, sizes, and can be readily distinguished from other Auchennorrhyncha by having one or more rows of small spines extending the length of hind tibiae. Many of the members of Cicadellidae are very serious crop pests resulting in damage to leaves and stems thus producing general symptoms like curling of leaves, bronzing drying, sooty mould followed by withering and death of plants. A few groups of leafhoppers genera acts as vectors and transmit phytopathogenic organisms that causes diseases and eventual death of plants. Some of the diseases caused by phytopathogenic organisms vectored by leafhoppers include little leaf of brinjal, sesamum phyllody, purple top role of potato, yellow dwarf of rice, rice tungro (Muniyappa and Veeresh, 1986), rice transitory yellowing, sandle spike, eastern wheat streak virus and maize streak virus, orange leaf of rice, etc., (Wilson and Claridge, 1991). Paddy is an important staple food crop preferred in Andhra Pradesh which occupies an area of 2.29 lakh 
hectares with a production of 1.18 million tonnes and productivity of $5042 \mathrm{~kg} \mathrm{ha}^{-1}$ (Department of Agriculture, 2018). Studies on insect fauna especially leafhopper fauna, associated with paddy crop ecosystems of Rayalaseema region were not attempted earlier.

\section{Materials and Methods}

Leafhoppers specimens were collected from different Agro-climatic zones of Rayalaseema by sweep netting in rice. About 10-15 to and fro net sweepings were taken each time and Leafhoppers collected were aspirated from the net into a glass tube and killed with a cotton swab wetted with a few drops of ethyl acetate.

The killed specimens were transferred to homeopathic vials, labelled, brought to the laboratory and dried in a hot air oven at 45$50^{\circ} \mathrm{C}$, for about 5 to 6 hours. For mounting and preparing slides of genitalia the procedure suggested by Knight (1965) was followed. For describing the different body parts the terminology suggested by Blocker and
Triplehorn (1985) was followed.

\section{Results and Discussion}

In the present studies fourteen leafhoppers species viz., Balclutha saltuella (Kirschbaum), Balclutha thea (Kirschbaum), Cicadulina bipunctata (Melichar), Cofona spectra (Distant), Cofona unimaculata (Signoret), Empoascanara defecta (Dworakowska), Empoascanara indica (Datta), Empoascanara prima (Distant), Exitianus indicus (Distant), Exitianus nanus (Distant), Maiestas dorsalis (Motschulsky), Maiestas pruthii (Metcalf), Nephotettix nigropictus (Stal) and Nephotettix virescens (Distant) were collected, identified and described.

An illustrated key has been prepared to aid rapid and accurate identification of the common species of leafhoppers found associated with paddy eco-systems of Rayalaseema. For those species which were not studied here, literature or a Taxonomist working on the leafhoppers may be consulted.

1. Mostly larger insects, clypeus and clypellus swollen; caudal end of aedeagus bifurcated. Length of leafhopper definitely exceeds $4 \mathrm{~mm}$; mostly in between 4-5 $\mathrm{mm}$

- Mostly smaller to medium sized insects, a pair of conspicuous black spots are present on the base of the scutellum slightly below the posterior margin. Clypeus and clypellus not swollen; length of leafhopper always less than 4 $\mathrm{mm}$. 3

2. Pale whitish brown coloured insects. Vertex with four black spots, two central at base and the other two on lateral margins of face. The central black spot at the margin of face and vertex is distinct (Figs. 1a-b). Cofona spectra (Distant)

- These are smaller than Cofona spectra, pale yellowish white coloured insects. Vertex without a distinct central dark spot at margin. Two larger spots on the anterior margins, two very small spots on disc (Figs. 2a-b)....Cofona unimaculata (Signoret)

3. Vertex with a single large spot / two black spots or with conspicuous black band

- Vertex without spots / conspicuous black band. 
4. Vertex with thick black band between the compound eyes. Fore wings with four apical and three anteapical cells. Pygofer with two conspicuous spines; upper spine is larger than the lower spine, aedeagus simple and curved, apex notched (Figs. 3ac). Exitianus indicus (Distant)

- Vertex with one large black spot/with a pair of black spots.....................................5

5. Yellowish orange coloured insects; dorsal side of the abdomen black in colour. Vertex with a pair of round black spots. Pygofer with a curved, bifid process. A robust subapical spine is seen on pygofer; aedeagus short and 'C' shaped (Figs. 4a-b)

\section{Cicadulina bipunctata (Melichar)}

- Vertex with a large central black spot which is irregularly margined. Pygofer lobe with curved dorsal processes. Subgenital plates wider at middle narrow towards apex. Aedeagus abruptly narrowed towards apex (Figs. 5a-b)

Empoascanara indica (Datta)

6. Medium to large sized insects; yellowish green to green in colour; width of the vertex more than half the width of the pronotum

- Small to medium sized insects; width of the vertex less than half the width of the pronotum

7. Aedeagus without any process, aedeagus articulated to connective with a membranous joint. Aedeagal shaft may be symmetrical / asymmetrical but definitely curved dorsad. .8

- Aedeagus with processes

8. Aedeagal shaft without any processes, articulated in side view, aedeagal appendages longer, convergent apically with distinct transverse ledges in terminal half (Fig.6ac). Empoascanara defecta (Dworakowska)

- Dorsal pygofer processes almost triangular in profile. Aedeagus with a single dorsally curved shaft; gonopore subapical. Aedeagus bent in the form of ' $\mathrm{C}$ '. Connected short, arms of the connective widely seperated at their base. Subgenital plates sclerotised at their margins (Figs. 7a-c)

Empoascanara prima (Distant)

9. Green coloured insects with black patch / black stripe on fore wings.

- Brown coloured insects with a pair of conspicuous black spots at the base of the scutellum slightly below the posterior margin/ fore wings with distinct zig-zag markings / pronotum greyish ochraceous with irregular row of minute black markings near the anterior margin

10. Medium to large sized insects with green coloured fore wings. Fore wings with a black patch, this does not reach the claval region. Aedeagus with a pair of lateral apophysis, dorsal surface elongated, sclerotised with four pairs of spines laterally (Figs. 8ab) ............................................ephotettix virescens (Distant)

- Medium to large sized insects with green coloured fore wing. Anterior margin of pronotum and inner margin of clavus of fore wing with a black stripe. Aedeagus which a pair of lateral apophyses; dorsal surface elongated; sclerotized with eight pairs of spines laterally and directed towards apex and gonopore apical (Figs. 9ac) Nephotettix nigropictus (Stal) 
11. Pygofer twice as long as height

- Pygofer not as above and with four dark brown and black spines along apical margin which are more or less equal size. A pair of conspicuous black spots on the base of the scutellum slightly below the posterior margin. Aedeagus slightly curved having articulation between base and shaft. Gonopore large and sub apical (Figs. 10a-

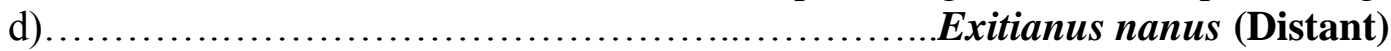

12. Aedeagus rather uniform width in lateral aspect, slightly curved, apically rounded except for acutely pointed ventral margin which extends beyond gonopore (Figs. 11ac). Maiestas pruthii (Metcalf)

- Aedeagal shaft wider basally, tapering gradually with acute apex and gonopore sub apical. Fore wings with distinct reddish brown zig- zag markings (Figs. 12ac) Maiestas dorsalis (Motschulsky)

13. Cream to pale yellowish brown coloured insects. Aedeagus elongate simple and narrow; gonopore apical (Figs.13a-b)

Balclutha saltuella (Kirschbaum)

- Green coloured insects. Aedeagus simple, filamentous, curved distad and aedeagus shaft evenly curved (Figs.14a-c)

Balclutha thea (Kirschbaum)

The most brief and important taxonomic and morphological characters of the above keyed species were provided here under for confirmation of identifications.

\section{Cofona spectra (Distant)}

Pale yellowish white in colour. Vertex with a black spot towards posterior margin and a central spot at the margin of face and vertex. Two spots on the margin near eyes and located more towards the face. Clypeaus and clypellus are swollen. Forewings subhyaline with four apical and three anteapical cells and appendix is present. Pygofer broader than its length in lateral view with submarginal macrosetae. Subgenital plates broader at base and gradually narrowed to an acute apex with marginal macrosetae. Connective with stem short, arms broad, strong and extended laterad. Aedeagus broad at the base gradually narrowed to a blunt apex in dorsal view. Aedeagus is ' $\mathrm{C}$ ' shaped with the caudal end bifurcated in lateral view.

\section{Cofana unimaculata (Signoret)}

Pale yellowish white, black spot on vertex. Clypeus and clypellus are swollen. Pygofer broader than its length in lateral view with macrosetae apically and hair like setae all over except in the apical portion. Subgenital plates broader at the base, abruptly narrowed at the basal one third and then gradually narrowed with submarginal macrosetae and marginal hair like setae. Connective stem short with a notch at apex, arms strong, long and extended laterad. Aedeagus broader at base and then uniform sided, caudal end bifurcated and gonopore apical.

\section{Exitianus indicus (Distant)}

Yellowish brown body with a black band between compound eyes. Forewings elongate, subhyaline with four apical and three anteapical cells and appendix wider. Pygofer with two conspicuous dark brown or black spines along the apical margin, upper spine is 
longer than lower spine and is wider and short. Styles with a sharp apophysis and distinct preapical lobe. Aedeagus simple, curved having an articulation between shaft and base, apex notched. Gonopore large and subapical.

\section{Cicadulina bipunctata (Melichar)}

Vertex with a pair of round black spots on the anterior margin. Vertex, pronotum and scutellum are yellowish orange in colour and the dorsum of abdomen is black in colour. Hemelytra hyaline with three apical and two anteapical cells. Pygofer with an elongate dorsal process which is bifid, with curved, short and robust ventral subapical spine. Connective ' $\mathrm{Y}$ ' shaped, arms close together, approximately equal in length to the stem. Aedeagal shaft cylindrical, ' $C$ ' shaped and curved dorsally with a pair of processes basally.

\section{Empoascanara indica (Datta)}

Vertex, pronotum and scutellum yellow. Vertex with a large central black spot. Forewings subhyaline with four apical cells. Anteapical cells and appendix are absent. Pygofer lobe more or less triangular in shape, broader at base and narrowed towards apex, with its dorsomesal processess curved, rounded at base and gradually narrowed towards apex; microsetae scattered all over the apical half. Styles long, outer margin bilobed in middle, inner margin straight, apical extension broadened at apex, cephalic end of styles shorter than caudal part which is gradually narrowed. Connective more or less ' $Y$ ' shaped, arms longer than stem, joined by a membrane at base. Aedeagus with its shaft simple, tubular, without any processes, broader at base, abruptly narrowed towards apex and gonopore subapical.

\section{Empoascanara defecta (Dworakowska)}

Stramineous in colour. Fore wings hyaline with four apical cells, the second being quadrangular in shape; anteapical cells and appendix absent. Pygofer lobe broad and long in the lateral view. Styles elongated, broad at apex and narrowed towards the base. Connective very short. Aedeagus very short, curved, appendages arising from aedeagus are longer and convergent apically with distinct transverse ledges in the apical portion.

\section{Empoascanara prima (Distant)}

Light yellow to yellowish orange in colour. Pronotum with conspicuous pit like structures. Forewings with four apical and two anteapical cells. Pygofer lobe rounded or angulated with a well defined sclerotised lobe like structure. Subgenital plates slightly sclerotised apically, lateral margins produced into a strong notch with micro setae. Connective loosely attached to aedeagus, inverted ' $\mathrm{Y}$ ' shaped in structure with arms widely seperated. Aedeagus ' $\mathrm{C}$ ' shaped with a strong curvature towards the lateral side.

\section{Nephotettix virescens (Distant)}

Yellowish green in colour. Fore wings with a black patch which does not reach the claval region, apical third black in males. Forewings subhyaline with four apical and three anteapical cells with broad appendix. Subgenital plates broader at base and gradually narrowed to an acute apex with submarginal macrosetae. Styles robust, highly sclerotised with longer apophyses, apex blunt. Aedeagus with a pair of lateral paraphyses, dorsal surface elongate, sclerotized with five pairs of spines laterally and directed towards apex. 
Fig.1-4 Cofona spectra (Distant): 1a.Aedeagus, lateral view; 1b. Style. Figs. 2a-b. Cofona unimaculata (Signoret): 2a. Aedeagus, dorsal view; 2b. Style. Figs. 3a-c. Exitianus indicus (Distant): 3a. Pygofer lobe, lateral view; 3b. Aedeagus, lateral view; 3c. Style. 4a-b. Cicadulina bipunctata (Melichar): 4a. Pygofer, lateral view; 4b. Aedeagus, lateral view

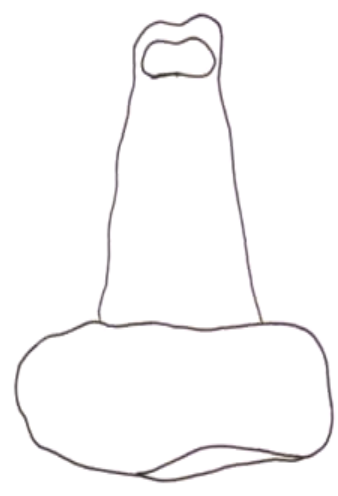

1a

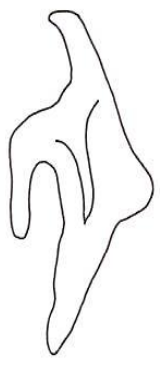

$1 b$

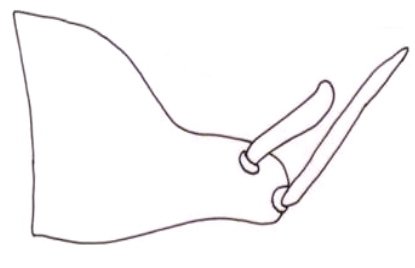

$3 a$

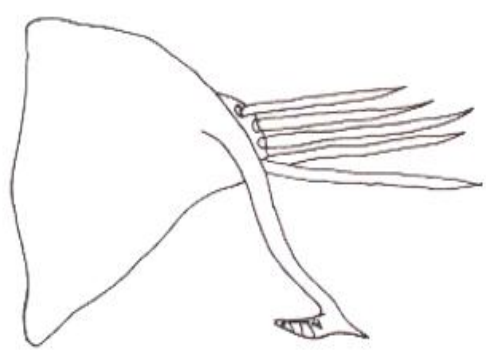

$4 a$

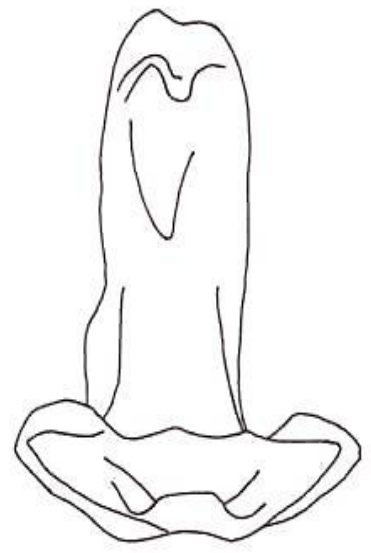

$2 a$

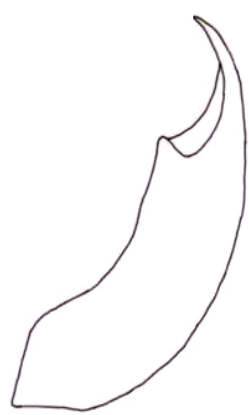

$3 b$

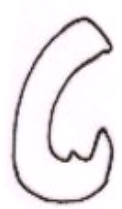

$4 b$ 
Figs.5-8 Empoascanara indica (Datta): 5a. Aedeagus, lateral view; 5b. Pygofer. Figs. 6a-c. Empoascanara defecta (Dworakowska): 6a. Subgenital plate; 6b. Aedeagus, lateral view; 6c. Style. Figs. 7a-c. Empoascanara prima (Osborn): 7a. Aedeagus; 7b. Connective; 7c. Pygofer. Figs. 8a-b. Nephotettix virescens (Distant): 8a. Aedeagus, lateral view (with four spines); 8b.

Pygofer lobe, lateral view (with five spines)

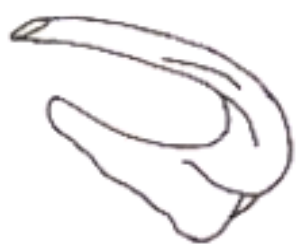

$5 a$

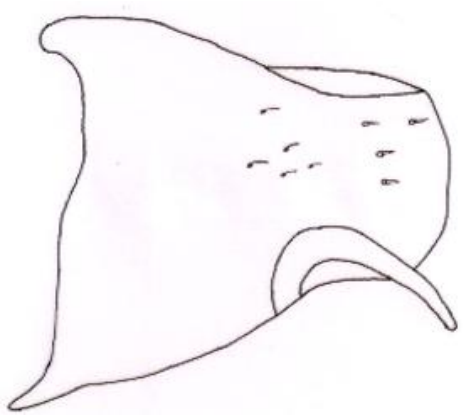

$5 b$

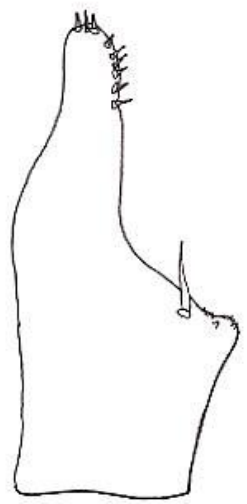

$6 a$

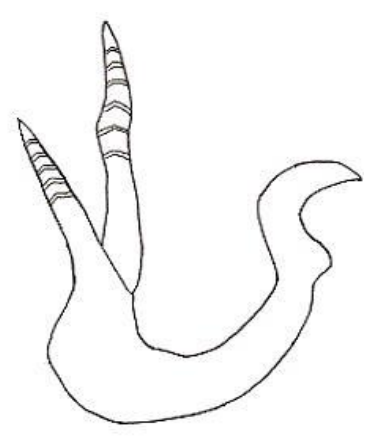

6b

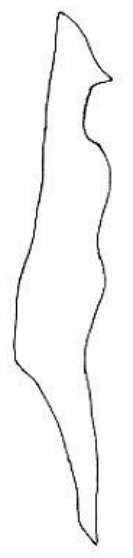

$6 c$

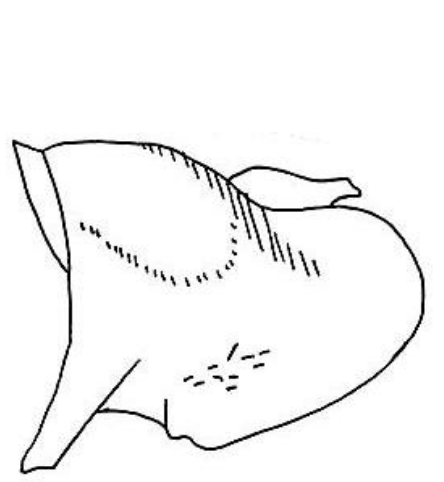

7c

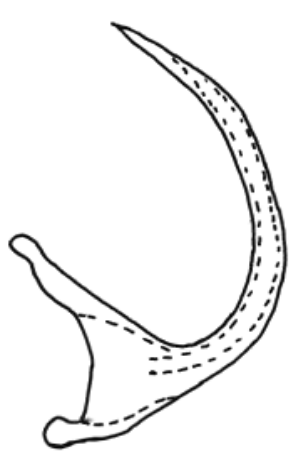

$7 a$

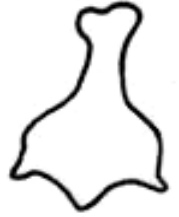

$7 b$

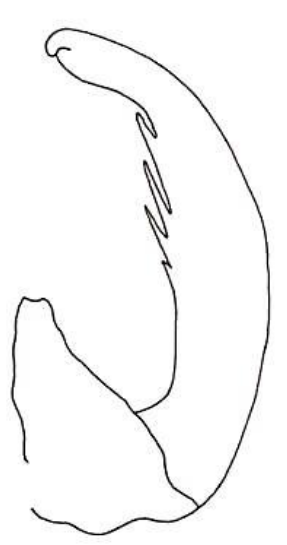

$8 a$

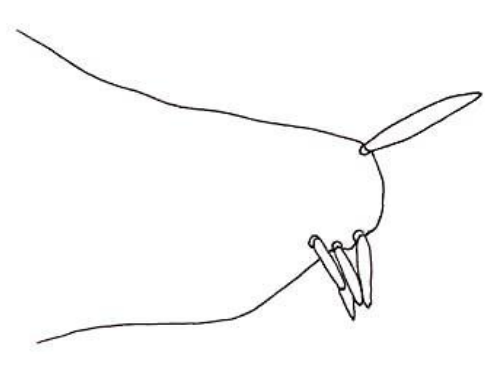

$8 b$ 
Figs.9-11 Nephotettix nigropictus (Stal): 9a. Aedeagus, lateral view; 9b. Connective; 9c. Style. Figs. 10a-d. Exitianus nanus (Distant): 10a. Aedeagus, lateral view; 10b. Connective; 10c. Style;

10d. Subgenital plate. Figs. 11a-c. Maiestas pruthii (Metcalf): 11a. Fused connective and aedeagus, lateral view; 11b. Style; 11c. Abdominal sternal apodemes

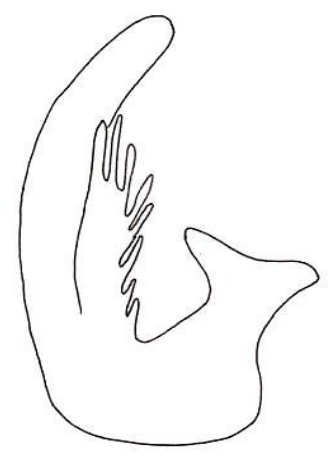

9a

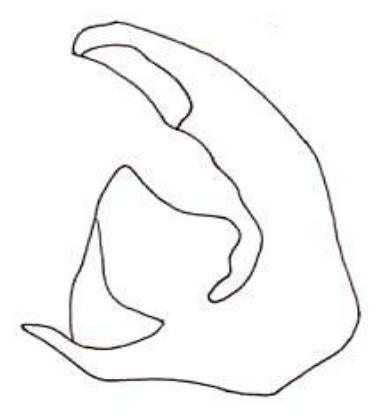

$10 a$

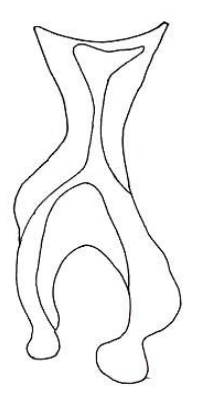

$9 b$

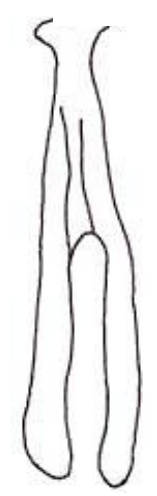

$10 \mathrm{~b}$

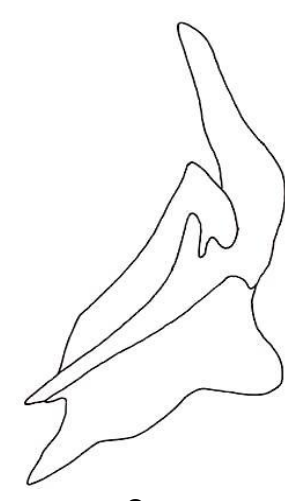

9c

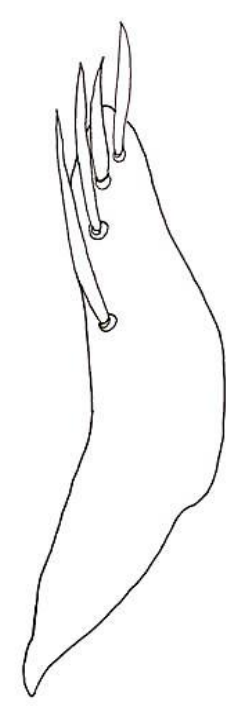

10d
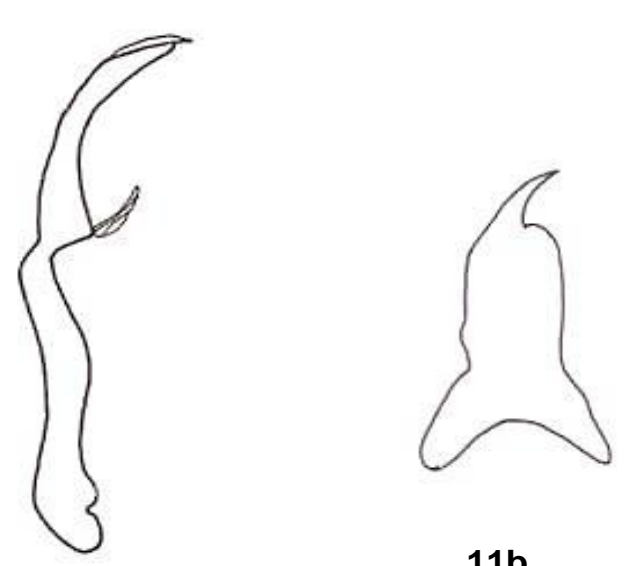

10c
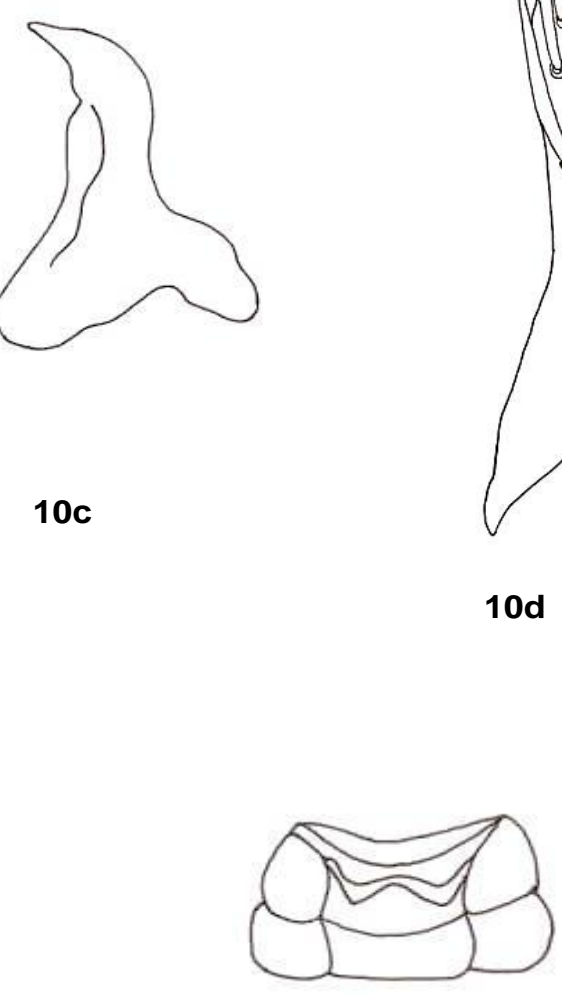

11c

11a 
Figs. 12-14 Maiestas dorsalis (Motschulsky): 12a. Abdominal apodemes lateral view; $12 \mathrm{~b}$. Style; 12c. Aedeagus. Figs. 13a-b. Balclutha saltuella (Kirschbaum): 13a. Style; 13b. Aedeagus, lateral view. Figs. 14a-c. Balclutha thea (Kirschbaum): 14a. Aedeagus in lateral view; 14b.

Style; 14c. Subgenital plate

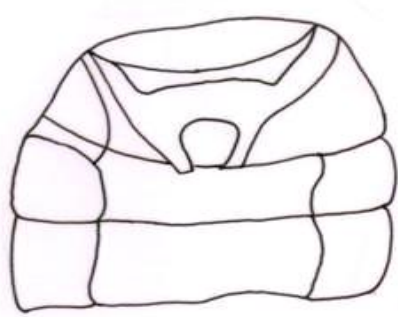

$12 a$

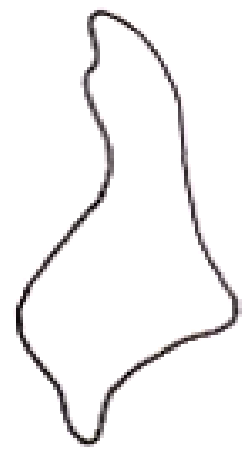

$13 a$

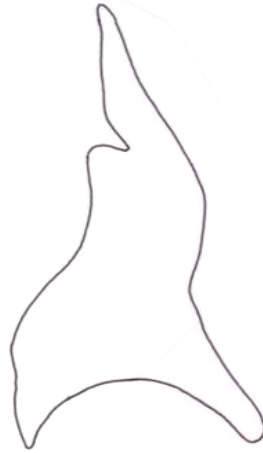

$12 b$

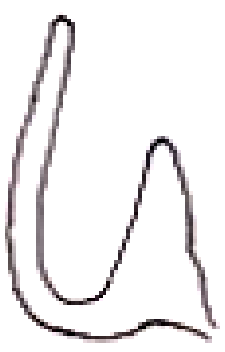

13b

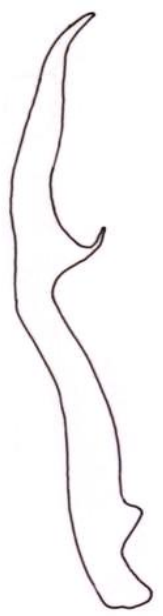

$12 \mathrm{c}$

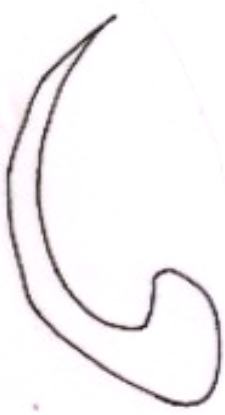

$14 a$

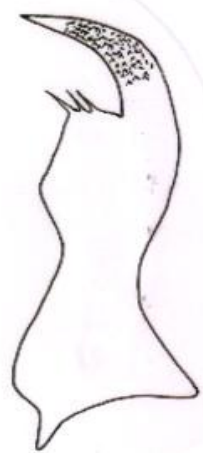

$14 b$

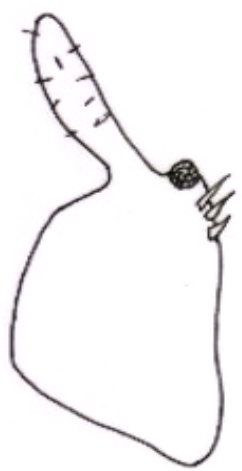

$14 c$ 


\section{Nephotettix nigropictus (Stal)}

Yellowish green in colour. Vertex with a black submarginal transverse band. Anterior margin of pronotum and inner margin of clavus of tegmina with a black stripe. Hemelytra subhyaline with four apical and three anteapical cells with broader appendix. Pygofer broader basally, gradually narrowed and apex with few black spines. Styles robust, sclerotized with longer apophyses. Aedeagus with a pair of lateral apophyses; dorsal surface elongate, sclerotized with eight pairs of spines laterally and directed towards apex, gonopore apical.

\section{Exitianus nanus (Distant)}

Stramineous in colour Vertex with a pale black band between compound eyes. A pair of conspicuous black spots are present at the base of scutellum slightly below the posterior margin of pronotum. Hemelytra elongate, subhyaline, with four apical and three anteapical cells and with a wider appendix. Pygofer with four dark brown or black spines along apical margin which are more or less equal in size. Styles with sharp apophyses and distinct preapical lobes. Aedeagus simple, slightly curved having articulation between base and shaft.

\section{Maiestas pruthii (Metcalf)}

Ochraceous in colour. Vertex pale brown, with a row of black minute but well defined markings at the anterior margin. Pronotum greyish ochraceous, with irregular row of minute black markings near the anterior margin. Sternal apodemes poorly developed. Subgenital plates triangular, lateral margin convex with a few strong marginal hairs. Apophysis of style slender, curved apically, and acutely pointed. Aedeagus rather uniform width in lateral aspect, slightly curved, apically rounded except for acutely pointed ventral margin which extends beyond gonopore.

\section{Maiestas dorsalis (Motschulsky)}

Pale yellowish brown, tegmina with distinct reddish brown zig-zag markings, hence commonly called as zig-zag leafhopper. Hemelytra subhyaline with four apical cells and three anteapical cells and with appendix. Subgenital plates wider basally, gradually narrowed towards apex, outer margins convex, with marginal macro and microsetae. Styles robust, apophyses slender and finger like. Aedeagal shaft wider basally, tapering gradually with acute apex and gonopore subapical.

\section{Balclutha saltuella (Kirschbaum)}

Cream to pale yellowish brown. Head wider than pronotum. Forewings are with three apical and two anteapical cells. Pygofer broadly rounded posteriorly, posteroventral margin slightly produced. Subgenital plates very short with fingers like apex. Connective with arms as long as stem. Aedeagus elongate simple, shaft narrow; gonopore apical.

\section{Balclutha thea (Kirschbaum)}

Green in colour, sometimes with darker green spots on vertex posteriorly and pronotum anteriorly. Subgenital plates with pronounced tooth laterally at midlength, uniseriate row of macrosetae, extending diagonally across ventral surface to medial edge of the plate. Connective ' $\mathrm{Y}$ ' shaped, stem very much longer than arms. Apophyses of style well developed with sharp ending and strongly arched. Aedeagus simple, filamentous, curved distad, and aedeagal shaft evenly curved.

This is the first study of leafhopper fauna associated with paddy crop ecosystems in Rayalaseema region of Andhra Pradesh. Bindra (1973) studied the host range, description and biology of 61 leafhoppers and stressed the need for identification of leafhopper species occurring in different crop 
ecosystems for the benefit of farmers, economic entomologists and extension workers. Sohi (1983) studied biosystematics leafhoppers belonging to the subfamily Typhlocybinae on cotton and rice crop ecosystems. Ahmed (1987) reported 33 Typhlocybinae leafhoppers, their host association, and associated yield loss in graminaceous crop ecosystems in Pakistan. Wilson and Claridge (1991) published a comprehensive account of leafhoppers in major rice growing areas of the world and keys for identification of leafhoppers along with colour photographs. Virakatamath (1983) emphasized the need of keys for leafhopper fauna of Karnataka and provided a key for identification economically important leafhoppers. Rao et al., (2000) reported 26 leafhoppers belonging to 12 genera associated with rice and sugarcane crop ecosystems along with keys for distinguishing these leafhoppers from Telangana (erstwhile Andhra Pradesh). Kamala (2001) reported wide spread occurrence of $N$. viresence and $N$. nigropictus in coastal Andhra Pradesh on rice crop. Shashank (2009) reported 20 leafhopper species associated with rice crop ecosystems of coastal and central Karnataka.

\section{References}

Ahmed, M 1987. Host associations and losses to growth and yield to some vegetable plants caused by Typhlocybine leafhoppers (Cicadellidae) in Pakistan. Proceedings of $2^{\text {nd }}$ International Workshop on leafhoppers and plant hoppers of economic importance, $28^{\text {th }}$ July- $1^{\text {st }}$ August 1986, Eds Wilson M R and Nault L R, CIE, provo, Utah, USA. 243-250.

Andhra Pradesh agricultural officers association, Department of Agriculture. 2018. Plant doctors dairy. 3.

Bindra, O.S 1973. Cicadellid vectors of plant pathogens. Final report of the PL-480 Project No.A7-ENT-22 Grant No.FGIM-300 completed on October 13, 1971. Department of Entomology, Punjab Agricultural University, Ludhiana, India. 1-56.

Blocker, H.D and Triplehorn, B.W. 1985. External morphology of leafhoppers. In, the leafhoppers and planthoppers (eds Nault, L.R and Rodriguez, J.G). John Wiley and Sons, New York. 460.

Giridhar, V., Rao, V.R.S and Prasad, K.V.H. 2008. Leafhopper fauna (Hemiptera: Cicadellidae) associated with sugarcane ecosystem of south India. Current Biotica. 2 (3): 287-299.

Kamala, G. 2001. Leafhopper fauna associated with rice-ecosystems in coastal Andhra Pradesh. M.Sc. (Ag.) thesis. Acharya N G Ranga Agricultural University, Rajendranagar, Hyderabad.

Knight, W.J. 1965. Techniques for use in the identification of leafhoppers (Homoptera: Cicadellidae). Entomologist's Gazette. 16(4): 129136.

Muniyappa, V and Veeresh, G.K. 1986. Arthropod vectors of virus and mycoplasma diseases of plants in India. Colemania. 2: 19-38.

Rao, V.R.S., Singh, J.P and Sudhakar, T.R. 2000. Leafhoppers fauna associated with rice and sugarcane crop ecosystems of Telangana region in Andhra Pradesh. Indian Journal of Entomology. 62 (1): 43-52.

Shashank, P.R. 2009. Taxonomic studies on leafhopper and planthopper fauna associated with rice ecosystem and their management. M.Sc. (Ag.) thesis. Acharya N G Ranga Agricultural University, Lam, Guntur.

Sohi, A.S. 1983. The oriental Typhlocybinae with special reference to the pests of 
cotton and rice. A review, In Proceedings of the $1^{\text {st }}$ international workshop on Biotaxonomy, classification and biology of leafhoppers and planthoppers (Auchenorrhyncha) of economic importance (eds) Knight, W. J. Pant N.C., Roberson, T.S., and Wilson, M.R.). Commonwealth Institute of Entomology. 56, Queens Gate, London. 49-74.

Viraktamath, C.A. 1983. Genera to be revised on a priority basis. In proceedings of the first international workshop on leafhoppers and plant hoppers of economic importance, W J Knight, $N$ $C$ Pant, $T S$ Robertson and Wilson $M$
$R(E d s$.$) . Common Wealth Institute of$ Entomology, London. 471-492.

Viraktamath, C.A. 2006. Final report of emeritus scientist project on taxonomic studies on the economically important leafhoppers (Hemiptera: Cicadellidae) of the Indian subcontinent. Department of Entomology, University of Agricultural Sciences, GKVK, Bangalore. 65-70.

Wilson, M.R and Claridge, M.F. 1991. Handbook for identification of leafhopper and palnthoppers of rice. $C A B$ International, Wallingford. Oxon, U.K.142.

\section{How to cite this article:}

Nagesh, S., Chalam, M.S.V., Koteswara Rao, S.R. and Ravindra Reddy, B. 2018. Leafhopper Funa Associated with Paddy Crop-Ecosystems in Rayalaseema Region of Andhra Pradesh, India. Int.J.Curr.Microbiol.App.Sci. 7(08): 904-915.

doi: https://doi.org/10.20546/ijcmas.2018.708.103 